\title{
The Road to Economic Self- Sufficiency: Job Quality and Job Transition Patterns after Welfare Reform
}

\begin{abstract}
This paper analyzes the relationships of schooling, the skill content of work experience, and different types of employment patterns with less-skilled women's job quality outcomes. Survey data from employers and longitudinal data from former and current welfare recipients are used for the period 1997 to early 2002. The analysis of job quality is broadened beyond employment rates and wages measured at a point in time by including non-wage attributes of compensation and aspects of jobs that affect future earnings potential. This study shows the extent to which lack of employment stability, job skills, and occupation-specific experience impedes welfare recipients' abilities to obtain a "good job" or to transition into one from a "bad job." The business cycle downturn has significantly negatively affected the job quality and job transition patterns of former and current recipients. () 2003 by the Association for Public Policy Analysis and Management.
\end{abstract}

\section{INTRODUCTION}

The Personal Responsibility and Work Opportunity Reconciliation Act (PRWORA) of 1996 abolished Aid to Families with Dependent Children (AFDC), the program through which eligible families were entitled to cash assistance, and replaced it with Temporary Assistance to Needy Families (TANF), a time-limited block grant program. TANF requires recipients to participate in work or work-based activities in order to receive cash assistance. TANF's work participation mandates have shifted the focus of welfare-to-work programs away from education and training toward immediate job placement. The emphasis on quickly placing recipients in employment is based on the premise that the best way to succeed in the labor market is to take any job, even one that may not pay well and may not be full-time (Brown, 1997). This "quick labor force attachment model" assumes that women who take low-paying and part-time jobs will eventually move up to higher-paying and fulltime jobs (Pavetti and Acs, 2001).

Two fundamental assumptions will determine whether PRWORA can both reduce welfare caseloads and increase economic well-being: that almost all recipients can get and keep jobs; and that consistent work will eventually lead to a living wage and economic self-sufficiency. Regarding the first assumption, postPRWORA caseloads declined by 50 percent in the first 5 years and former and current welfare recipients entered the labor market at much greater rates than in

Manuscript received April 2002; out for review April 2002; review completed June 2002; revision completed December 2002; accepted February 2003.

Journal of Policy Analysis and Management, Vol. 22, No. 4, 615-639 (2003)

(C) 2003 by the Association for Public Policy Analysis and Management

Published by Wiley Periodicals, Inc. Published online in Wiley InterScience (www.interscience.wiley.com) DOI: 10.1002/pam.10158 
616 / Job Quality and Job Transition Patterns after Welfare Reform

the past. ${ }^{1}$ Much of the reform's success in moving so many recipients from welfare to work is due to its implementation during a period of extremely low unemployment and strong economic growth, which began about 5 years prior to and ended about 5 years after welfare reform. One, as of yet, unknown issue is whether the employment gains of former and current recipients will be jeopardized by the recession that began in early 2001 .

With respect to the second assumption, little is known about the extent of employment continuity once recipients start jobs, or about the quality of jobs they obtain. Also, evidence is limited and conflicting about the likelihood that consistent work will eventually lead to economic self-sufficiency for former recipients-many of whom have low levels of education, work skills, and work experience. Nor is there evidence about the paths by which work experience affects job quality. For instance, are recipients and ex-recipients more likely to move into jobs that pay a living wage and provide health benefits by moving up within a firm or by switching employers? Does the skill content of work experience affect the likelihood of moving into fulltime jobs that pay a living wage? To what extent have the worsening economic conditions in 2001-2002 affected job transition patterns and the probability of earning a living wage? This study is among the first to provide direct evidence that offers insight into how the quality of employment outcomes and job transition patterns of former and current TANF recipients are affected by the skill content of work experience and changes in economic conditions.

The current emphasis of state welfare programs on immediate job placement, with little attention to the quality of these jobs, may mean that many TANF recipients begin work in a bad job (e.g., a part-time job paying less than $\$ 7$ per hour, with no health insurance) because they lack the job skills required for a job that offers the greatest chances for upward mobility. If this happens, will these women be relegated to a low-wage job ghetto-that is, a dead-end job that lacks training opportunities, that is unstable, and that does not pay enough to support their children? Or will steady work in a bad job increase the probability of moving into a good job?

This paper provides evidence on job quality, job skills, and employment patterns of former and current TANF recipients over a 5-year period (1997 to early 2002). Two new data sets were analyzed - a panel study of single mothers who received cash welfare in February 1997, and a telephone survey of a random sample of employers. Both surveys were administered between 1997 and early 2002 in Michigan. The same sets of questions about job tasks and work skills were asked in each survey. The Women's Employment Survey (WES) is a four-wave, in-person survey of a random sample of women from an urban Michigan county who received cash welfare in February 1997. These data were analyzed: to examine the quality of jobs held at each wave; to examine the skill content of their recent work experience; and to assess the extent of job stability and job mobility between waves. A series of job quality indices is developed based on the wages, health benefits, and hours of jobs. The WES data cover the period 1997 to early 2002, allowing for examination of the effects of changes in local economic conditions.

The Michigan Employer Survey (MES) is a random sample of employers in three large metropolitan areas in Michigan. These data were analyzed to document the quality of recently filled entry-level jobs that did not require a college degree, focusing on hourly wage, health benefits, and hours of the job. Employers' reports of the skills required (for example, reading, writing, arithmetic, computer, customer com-

${ }^{1}$ The rate of caseload decline, however, outpaced the increase in employment rate among former and current recipients during this period. 


\section{Job Quality and Job Transition Patterns after Welfare Reform / 617}

munication skills) in recently filled jobs are compared with the skills and previous job task experience of the WES respondents.

The WES data is used to examine the relationships of schooling, the skill content of work experience, and different types of employment patterns with job quality outcomes. Also compared are the quality of employment outcomes, job transition patterns, and the probability of successfully transitioning to a good job, in the 1997-1999 period of tight labor demand with these employment patterns in the 2000 to early 2002 period of a more sluggish economy.

A primary goal of this study is to shed light on the pathways through which successful transitions into good jobs are made. This study shows the extent to which lack of employment stability, job skills, and occupation-specific experience impede welfare recipients' abilities to obtain a "good job" or to transition into one from a "bad job." The results indicate that the recession already has had significant negative effects on job quality and job transition patterns.

\section{RELATED STUDIES}

\section{Skill Requirements}

Earnings inequality within groups defined by education, age, and experience has steadily increased over the past three decades (Katz and Murphy, 1992). A shift in demand for worker characteristics unobserved in data sets like the Current Population Survey (CPS) is a principle hypothesis advanced to explain this trend (Juhn, Murphy, and Pierce, 1993; Katz and Murphy, 1992; Levy and Murnane, 1992). Recent research has documented the growing importance of cognitive skills in wage determination, for all workers, as well as for less-educated workers (Jencks and Phillips, 1998; Murnane, Levy, and Willett, 1995; Tyler, Murnane, and Willett, 2000). However, the explanation of increasing returns to dimensions of skill not proxied by educational attainment has not resolved the puzzle as to which particular job skills have become relatively more valued in the labor market (DiNardo and Pischke, 1997; Krueger, 1993).

A lack of basic skills-reading, writing, simple arithmetic, basic familiarity with computers-may explain why some welfare recipients have difficulty obtaining a good job (Holzer, 1996; Holzer, Stoll, and Wissoker, 2001). In addition to attributes that employers have always looked for-reliability, positive attitude, and willingness to work hard-employers now look for hard skills (e.g., reading, writing, math, and computer skills) and soft skills (e.g., ability to work in groups of various backgrounds, and to communicate effectively) that entry-level applicants might not have needed 20 years ago (Murnane and Levy, 1996).

\section{Job Quality}

Some evidence documents that many low-skilled workers attain only poor quality jobs, with low wages and minimal benefits. In 1998, 60 percent of poor families had one or more workers, and 20 percent included one or more full-time workers (Guyer and Mann, 1999). Also in that year, 35 percent of working parents whose income was below 200 percent of the poverty level were uninsured. This suggests that many jobs available to former TANF recipients may not provide health insurance. In Michigan, the state from which our data are drawn, working parents who are not on welfare are ineligible for Medicaid if their earnings exceed 46 percent of the poverty level (\$6141 a year for a family of three). Working, single mothers are 
618 / Job Quality and Job Transition Patterns after Welfare Reform

eligible to receive transitory Medicaid assistance up to 12 months after leaving TANF, but eventually Medicaid eligibility will be exhausted.

\section{Making the Transition from Bad Job to Good Job}

While there is consensus that initial wages are likely to be low for less-skilled workers, there is no consensus about their potential for movement into a good job. Some analysts think that low-wage jobs without health benefits represent a port of entry into higher-paying jobs with health benefits, whereas others are concerned that entry-level jobs simply represent the first in a succession of dead-end jobs (Connolly and Gottschalk, 2001; Edin and Lein, 1997).

Studies of women who have left AFDC find low-paying jobs to be the norm and little wage growth in the first several years after leaving welfare (Cancian et al., 2000; Harris, 1996; Pavetti, Holcomb, and Duke, 1995; Riccio, Friedlander, and Freedman, 1994). Burtless (1995), using National Longitudinal Survey of Youth (NLSY) data, showed that women with low levels of schooling and low Armed Forces Qualification Test (AFQT) scores had lower rates of wage growth with age than did other women, and conjectured that these low rates of wage growth reflect recipients' low skill levels.

Loeb and Corcoran (2001), on the other hand, claim that AFDC recipients experienced low rates of wage growth with age because recipients worked fewer years and were more likely to work part-time, relative to non-recipients. They report that wage growth per years actually worked is similar for AFDC recipients and nonrecipients (roughly 6 percent for every year of full-time work), and that wage growth is slow when individuals work part-time. Gladden and Taber (2000) find no significant differences in wage growth with experience by educational attainment.

Neither Loeb and Corcoran (2001) nor Gladden and Taber (2000), however, consider the dimensions of skill not proxied by educational attainment and experience. That is, their estimates include both individuals in jobs that require only soft skills, who may gain little or nothing from work experience, and individuals whose job requires hard skills (e.g., reading, writing, math, or computer skills) who may experience significant gains from work experience. This study directly tests whether the skill and task content of work experience affects movement from bad jobs into good jobs.

There are two possible routes to a good job from a bad job. In one case, a worker remains at the same firm and experiences an upgrade in pay and benefits due to raises or promotions. Or, a worker might accumulate work experience in a bad job and then change employers to get a better job. Topel and Ward (1992) and Loprest (1992) highlight the importance of job mobility (that is, job-to-job transition) to early career wage growth, estimating that job changes account for roughly one-third of total wage growth during the first 10 years in the market. These studies, however, are based on samples of better-educated workers. Royalty (1998) and Holzer and LaLonde (2000) show that the kinds of job-to-job changes that can have positive effects on the earnings of young workers are relatively infrequent among young, less-educated women, while job-to-nonemployment changes occur more frequently among this group. The WES data allow direct examination of job-to-job transitions between waves, and assessment of the extent to which job mobility facilitates movement into good jobs.

Connolly and Gottschalk (2001) evaluate the extent to which bad jobs can be considered good in that they allow individuals to develop job skills and offer onthe-job training opportunities that enable them to get better wage offers in the future. They find that high school dropouts experience both lower wage growth within jobs and lower wage growth in starting wages across jobs than do females with more education. 
Pavetti and Acs (2001) examine the employment transitions of young women into and out of unemployment, bad jobs, and good jobs. They define good jobs as those that are full-time and pay at least $\$ 8$ per hour. Pavetti and Acs predict that about a quarter of women who ever receive welfare will work primarily in good jobs by their late 20s. However, their estimates of transition rates are based on the work experience of women who have never received welfare, and may well overstate recipients' employment prospects, if welfare mothers possess unobservable personal and human capital characteristics that negatively affect employment outcomes.

\section{Local Labor Market Demand Conditions}

A number of studies have tried to estimate the effect of the business cycle or local labor market conditions on welfare caseloads over the 1980s and 1990s (e.g., Hoynes, 2000; Wallace and Blank, 1999; Ziliak et al., 2000); but less evidence has been brought to bear on how welfare recipients' labor market outcomes are affected (Holzer, 1999a). Previous research has shown that less-skilled workers are more affected by changes in local economic conditions-they are more likely to have reductions in employment and earnings during a downturn, and also more likely to have gains during periods of economic expansion (Hoynes, 2000).

Former and current recipients may be even more sensitive to the business cycle. Unstable work history may be penalized because firms use education and employment history to signal the likelihood of a successful job match. Many welfare recipients have spent substantial time out of the labor force. Because WES provides data on earnings and employment characteristics over a 5-year period that has significant variation in labor market demand conditions, their sensitivity to the business cycle can be directly investigated.

In summary, this study offers insight into how the quality of employment outcomes and job transition patterns of former and current TANF recipients are affected by the skill content of work experience and by changes in economic conditions.

\section{DATA SETS AND VARIABLE DEFINITIONS}

\section{Datasets}

\section{The Women's Employment Survey (WES)}

The Women's Employment Study drew a random sample of single mothers who received cash assistance in February 1997 in an urban Michigan county. To be eligible for the sample, the women had to reside in this county, be a U.S. citizen between the age of 18 and 54, and be either Caucasian or African American. Interviews were conducted in Fall 1997, Fall 1998, Fall 1999/Winter 2000, and Fall 2001/Winter 2002. The response rate was 86 percent for the first wave $(\mathrm{N}=753), 92$ percent for the second wave $(\mathrm{N}=693), 93$ percent for the third wave $(\mathrm{N}=632)$, and 91 percent for the fourth wave of this panel study $(\mathrm{N}=577){ }^{2}$ The fourth wave occurred between 56 and 61 months after the sample was drawn.

The sample was drawn as the transition from the old welfare system to the new one was being implemented. Whereas all respondents received cash assistance in

\footnotetext{
${ }^{2}$ Respondents interviewed at the first four waves represent 67 percent of the original sample, i.e., 0.86 $\times 0.92 \times 0.93 \times 0.91$.
} 
February 1997, about one-quarter had left welfare by fall 1997, one-half by fall 1998, 70 percent by fall 1999, and 75 percent by fall 2001 .

We use many measures not available in other studies, including information about work history, welfare history, basic job skills, hourly wage of their main job, number of hours worked in this job, and whether they received employer-provided (and partially financed) health benefits. The human capital variables from WES include: years of schooling; years of full-time and part-time work experience; occupation in which recipient has previous work experience; number and type of job tasks ever performed on a daily basis in any previous job held. Type of job tasks include reading and writing paragraph-length material, arithmetic, customer communication skills, and use of computer (on a daily basis). ${ }^{3}$ The physical and mental health and safety measures include: physical limitations, mental health measures, child health problems, and experience of severe abuse.

\section{The Michigan Employer Survey (MES)}

In the fall of 1997 (when the initial wave of WES was underway), Harry Holzer administered a telephone survey to 900 establishments in three large metropolitan areas in Michigan. The employers were drawn from a sample stratified ex-ante by employer size, so that the sample roughly represents the distribution of the workforce across establishment size categories. The survey was administered to the individual who was responsible for entry-level hiring, and to all establishments that had hired someone within the past two years. Conditional on meeting these criteria, response rates averaged over 70 percent (Holzer, 1999b).

Each employer was asked a series of questions about the characteristics of the most recently filled position that did not require a college degree. Because the firms are represented in proportion to the number of workers they employ, this sample of recently filled non-college jobs constitutes a representative sample of the jobs available in local labor markets over a period of several months (Holzer, 1996). Employers were also asked a similar series of questions about the characteristics of jobs filled by welfare recipients within the 2 years previous to the survey. Questions focused on: the hourly wage, hours, and health benefits offered in the job; the occupation and position in which this worker was hired; the credentials and skills employers sought and the hiring criteria used; and the daily task requirements of the job, where the job task measures are identical to those used in WES.

Given the high response rates and the extensive survey instruments, these data sets provide complementary evidence from the supply and demand sides on the relationships between job skill requirements, job transition patterns, and job quality for former and current recipients in the post-welfare reform era. ${ }^{4}$

\footnotetext{
3 The job task questions were developed from Holzer (1996).

${ }^{4}$ Michigan's welfare policies are quite similar to those of many other states. For example, women in Michigan who worked part-time at minimum wage jobs were at the median for monthly net income among 12 states that contained a large portion of the nation's population and about half of the 1998 caseload (Acs et al., 1998). Furthermore, the fraction of women in our sample who are employed, the fraction who have left welfare, and the fraction who have left welfare and are working but do not have employersponsored health insurance, are all very similar to the results of a recent MDRC report on Cleveland (Brock et al., 2002), results in Wisconsin from a study by Cancian et al. (2000), and very similar to those reported by Acs and Loprest (2001) at the Urban Institute using administrative data from the Washington, DC area. Because of the similarities in the fraction working across all of these studies, we do not expect our results to differ from those that would be found in other studies if these other studies had measured the same things using the same models. While the study uses data from only Michigan, the policy and economic conditions in Michigan are broadly representative of the majority of the TANF caseload.
} 
Job Quality and Job Transition Patterns after Welfare Reform / 621

\section{Variable Definitions}

\section{Job Quality Index}

At what point does a family have sufficient income and resources (such as health benefits) to meet its needs adequately? At least 50 U.S. cities and counties have enacted living wage ordinances since 1994, which require businesses with city contracts or subsidies to offer wages (and in some cases fringe benefits) well above the level required by the state and federal government. The living wage ordinance in Detroit (which is similar to that in other localities) is indexed to the federal poverty level for a family of four (currently \$8.83) with health benefits, or 125 percent of the federal poverty level (currently $\$ 10.44$ ) without health benefits.

Our measure of job quality is based on the wage, health benefits, and hours of a woman's primary job, and is similar to the notions embodied in living wage laws. We examine only the primary job because women who work full-time on their main job are more likely to experience wage growth than are individuals who work full-time hours but whose hours are spread between a main job and another job. (Only 7 percent of the sample reported multiple jobs.) We define a "good" job as one that is fulltime (at least 35 hours per week), pays at least $\$ 7$ per hour, and offers health benefits either immediately or after a trial period; or, as one that is full-time, pays at least $\$ 8.50$ per hour, and does not provide health benefits. Those whose current job satisfies these wage and benefit criteria but who work part-time are defined as having a good job if they are working part-time voluntarily. All other jobs are defined as "bad" jobs.

Table 1 shows the components of income and the net annual income (in 1999 dollars) received after taxes, transfer, and health insurance costs by a hypothetical single mother who has two children and works full-time at a "good" job. The last row of Table 1 compares this net income to the 1999 poverty line for a family of three. At \$7.00 per hour with employer-provided health benefits, the net annual income of a full-time worker is $\$ 15,997,19$ percent above the 1999 poverty line for a family of three. At $\$ 8.50$ per hour without employer-provided health benefits, the net income is $\$ 15,212,13$ percent above the 1999 poverty line.

The spectrum of job quality is continuous, and thus, any definition of a good job is inherently somewhat arbitrary. We, therefore, experimented with several alternative definitions of "good job" to test the robustness of the results, none of which qualitatively changed the underlying findings reported in this paper. (These results using alternative definitions of a good job are available from the authors upon request.) A problem that could arise with using health benefits as a criterion for a good job is that, because part-time jobs are much less likely to offer health benefits, the categorization of individuals in bad jobs may be driven by women's preferences for parttime work, rather than by the quality of their employment outcomes. Moreover, because the majority of the sample have preschool-aged children, part-time work may allow greater opportunities for flexible work hours. We alternatively define an individual as possessing a good job if she earns at least $\$ 7$ per hour and works fulltime, or voluntarily works part-time. Those who work part-time, but want to work more hours on their primary job, are categorized as working in a bad job. This alternative definition excludes health care coverage, but did not qualitatively change the findings. ${ }^{5}$ We report descriptive results using these alternative definitions in the text.

${ }^{5}$ Other specification checks using alternative thresholds of a good job (such as earning at least $\$ 6.50$ or classifying full-time as at least 30 hours a week) yielded similar overall patterns of results. 
Table 1. Income and the net annual income (in 1999 dollars) after taxes, transfer, and health insurance costs for a single mother of two who works full-time at a "good job."

\begin{tabular}{lcr}
\hline & $\begin{array}{c}\text { Wage }=\$ 7 / \mathrm{hr} \\
\text { w/Health Benefits }\end{array}$ & $\begin{array}{c}\text { Wage }=\$ 8.50 / \mathrm{hr} \\
\text { w/o Health Benefits }\end{array}$ \\
\hline 1) Gross annual income & $\$ 12,648$ & $\$ 15,348$ \\
2) Federal income tax (-) & $\$ 0$ & $\$ 0$ \\
3) FICA tax (-) & $\$ 972$ & $\$ 1,176$ \\
4) MI State income tax (-) & $\$ 379$ & $\$ 460$ \\
5) Earned income tax credit & $\$ 3,780$ & $\$ 3,204$ \\
6) Food stamps benefit & $\$ 1,740$ & $\$ 816$ \\
7) TANF benefit & $\$ 0$ & $\$ 0$ \\
8) Medicaid benefit & $\$ 0$ & $\$ 0$ \\
9) Private health coverage (-) & $\$ 840$ & $\$ 15,212$ \\
10) Net annual income & & \\
$(=[$ rows 1+5+6] - [rows 2+3+4+9]) & $\$ 15,977$ & $113 \%$ \\
1999 Federal Poverty Line for family & & $\$ 13,423$ \\
of 3 (parent, 2 children) & & \\
11) Net annual income as a & $119 \%$ & \\
percentage of Federal Poverty Line & & \\
\hline
\end{tabular}

These are conservative estimates as we have not included work expenses associated with child care costs and transportation costs.

Workers who do not have employer-provided health insurance often "do without." However, our interest is in the necessary wage that enables economic self-sufficiency and, because families cannot be truly self-sufficient without health insurance, we include health insurance costs in our calculations. Data for health costs were obtained from the National Medical Expenditure Survey and the Families USA report, Skyrocketing Health Inflation: 1980-1993-2000. We assume employees in the first scenario will pay one-third of the cost of the health insurance premium.

Since the Child Health Insurance Program (CHIP) covers health insurance for children of the working poor (up to $185 \%$ of the poverty line in Michigan), health insurance for children is not part of the health care costs we include.

We account for the monetary value of all government benefit sources for which the individual is eligible using 1999 Michigan policy/eligibility paramaters.

A respondent is defined as falling into one of three employment states at each interview date: unemployment, employment in a bad job, or employment in a good job. A priori, we cannot assume individuals who are unemployed at a point in time are worse off than those who have a bad job, since a longer job search may enable the unemployed to secure a good job. However, self-reported reservation wages suggest that the unemployed are having difficulty getting any job. Among women who were unemployed at the fall 1998 wave, 90 percent had reservation wages less than $\$ 7$ per hour, and only 2.3 percent had reservation wages greater than $\$ 8$ per hour. About two-fifths were willing to take a job at or below the minimum wage. Because almost all of the unemployed stated a willingness to take a bad job, we use the following hierarchy of employment states-good job, bad job, unemployed.

\section{Job-Transition Pattern Variables}

We characterize employment patterns and the extent of job stability and job mobility between waves, using retrospective questions from each wave on job tenure and 
monthly job and employment history over the past year. The wages, hours, and health benefits of the most recent job are recorded at each interview (given that the individual has worked at some point between interviews). ${ }^{6}$ Therefore, job separations are counted over the period between two interviews. ${ }^{7}$ If a person is between jobs at the time of an interview, the separation is assigned to the interview year when she starts her next job. Job separations are distinguished both by whether they were voluntary (defined as leaving a job for any reason other than being fired or laid-off) or involuntary, and by whether they were followed by a nonemployment spell of four or more weeks.

We define three patterns of job transitions: job stability, job mobility, and job instability. Individuals whose current or most recent job at wave $t$ was the same as that held at the previous wave are denoted as experiencing job stability. Job mobility occurs when respondents made a voluntary job change without experiencing any involuntary separations or transitions into nonemployment. Individuals experience job instability if they had at least one job-to-nonemployment transition or an involuntary separation from their primary job. ${ }^{8}$ A "transition" is defined as a job-to-job transition if the job change was voluntary and the interval between jobs was less than four weeks. Conversely, a transition is defined as a job-to-nonemployment transition if the spell of nonwork lasts four or more weeks, or if the job change results from being laid-off or fired. Royalty (1998) and Gladden and Taber (2000) use similar definitions of job transitions. (Appendix A provides further details on other variable definitions and measurement issues.)

\section{DESCRIPTIVE RESULTS}

Table 2 reports respondents' employment status at each wave and the wages, hours worked, and job characteristics of working respondents at each wave. Employment grew modestly from 61.8 percent in fall 1997 to 66.8 percent by fall 1999; and subsequently declined to 63.4 percent by fall 2001/winter 2002. While unemployment among these women declined by 8.3 percentage points between 1997 and 1999 when the economy was expanding, it rose by 7.8 percentage points between 1999 and 2001. Here the unemployed are defined as those who are not employed, but either worked or searched for work within the last year.

The quality of jobs held by hired former and current recipients improved between each wave. Median hourly wages increased by 15.9 percent (from \$5.99 to \$6.94) between fall 1997 and fall 1999 , and by 8.4 percent (from $\$ 6.94$ to $\$ 7.52$ ) between fall 1999 and fall 2001. The percent of employed women who worked full-time on their primary job rose from 46 percent in fall 1997 to 65 percent by fall 1999. This increase in full-time employment likely contributed to the large increase in the availability of health benefits on employed women's jobs-from 38 percent at wave 1 to 57 percent at wave 3. Full-time employment and the proportion of women working in jobs offering health benefits increased only slightly between fall 1999 and fall 2001.

\footnotetext{
${ }^{6}$ Since only about 10 percent of the sample did not work between waves (and thus lack wage information), selection bias should not be a major concern.

${ }^{7}$ Job change and employer change are used interchangeably here because data are insufficient to distinguish between the two.

${ }^{8}$ We compared the total number of job transitions with information on the total number of jobs held between waves, as well as information on jobs held concurrently and could account for nearly all primary job changes.
} 
624 / Job Quality and Job Transition Patterns after Welfare Reform

Table 2. Respondents' employment status at each wave.

\begin{tabular}{|c|c|c|c|c|c|c|c|}
\hline & $\begin{array}{l}\text { Wave } 1 \\
\text { Fall } 1997\end{array}$ & $\begin{array}{l}\text { Wave } 2 \\
\text { Fall } 1998\end{array}$ & $\begin{array}{l}\text { Wave } 3 \\
\text { Fall } 1999\end{array}$ & $\begin{array}{l}\text { Wave } 4 \\
\text { Fall } 2001\end{array}$ & $\begin{array}{l}\text { Change b/w } \\
\text { Fall '97-'99 }\end{array}$ & $\begin{array}{l}\text { Change b/w } \\
\text { Fall '99-'01 }\end{array}$ & $\begin{array}{l}\text { Change b/w } \\
\text { Fall '97-'01 }\end{array}$ \\
\hline \multicolumn{8}{|l|}{ Labor Market Status**: } \\
\hline Out of the Labor Force & $10.4 \%$ & $13.3 \%$ & $13.6 \%$ & $9.2 \%$ & $+3.2 \mathrm{pts}$ & -4.4 pts & $-1.2 \mathrm{pts}$ \\
\hline Unemployed & $27.9 \%$ & $21.8 \%$ & $19.6 \%$ & $27.4 \%$ & $-8.3 \mathrm{pts}$ & $+7.8 \mathrm{pts}$ & $-0.5 \mathrm{pts}$ \\
\hline Employed & $61.8 \%$ & $64.9 \%$ & $66.8 \%$ & $63.4 \%$ & $+5.0 \mathrm{pts}$ & $-3.4 \mathrm{pts}$ & $+1.6 \mathrm{pts}$ \\
\hline \multicolumn{8}{|l|}{ Among those Working: } \\
\hline \multicolumn{8}{|l|}{$\begin{array}{l}\text { Real Hourly Wages } \\
\text { (expressed in } 1999 \\
\text { dollars) }\end{array}$} \\
\hline Mean & $\$ 6.83$ & $\$ 7.20$ & $\$ 7.31$ & $\$ 8.25$ & $+7.0 \%$ & $+12.9 \%$ & $+20.8 \%$ \\
\hline Median & $\$ 5.99$ & $\$ 6.49$ & $\$ 6.94$ & $\$ 7.52$ & $+15.9 \%$ & $+8.4 \%$ & $+25.5 \%$ \\
\hline$\%$ Full-time*** & $45.6 \%$ & $59.6 \%$ & $64.9 \%$ & $67.7 \%$ & $+19.3 \mathrm{pts}$ & $+2.8 \mathrm{pts}$ & $+22.1 \mathrm{pts}$ \\
\hline$\%$ Part-time & $54.5 \%$ & $40.4 \%$ & $35.2 \%$ & $32.3 \%$ & $-19.3 \mathrm{pts}$ & $-2.8 \mathrm{pts}$ & $-22.1 \mathrm{pts}$ \\
\hline$\%$ Voluntarily Part-time & - & $13.6 \%$ & $13.6 \%$ & $12.9 \%$ & - & $-0.7 \mathrm{pts}$ & - \\
\hline$\%$ Underemployed**** & - & $26.8 \%$ & $21.6 \%$ & $19.5 \%$ & - & $-2.1 \mathrm{pts}$ & - \\
\hline$\%$ Working in Jobs & & & & & & & \\
\hline $\begin{array}{l}\text { Offering Health Benefits } \\
\text { (at any wage) }\end{array}$ & $38.1 \%$ & $54.4 \%$ & $57.1 \%$ & $62.8 \%$ & $+19.0 \mathrm{pts}$ & $+5.7 \mathrm{pts}$ & $+24.7 \mathrm{pts}$ \\
\hline \multicolumn{8}{|l|}{$\%$ Working Full-time } \\
\hline Earning $>=\$ 7 / \mathrm{hr}$ & $15.1 \%$ & $29.5 \%$ & $37.8 \%$ & $46.3 \%$ & $+22.7 \mathrm{pts}$ & +8.5 pts & $+31.2 \mathrm{pts}$ \\
\hline$\%$ Working in Bad Jobs & $86.5 \%$ & $71.2 \%$ & $61.9 \%$ & $54.2 \%$ & $-24.6 \mathrm{pts}$ & $-7.7 \mathrm{pts}$ & $-32.3 \mathrm{pts}$ \\
\hline$\%$ Working in Good Jobs & $13.5 \%$ & $28.8 \%$ & $38.1 \%$ & $45.8 \%$ & $+24.6 \mathrm{pts}$ & $+7.7 \mathrm{pts}$ & +32.3 pts \\
\hline
\end{tabular}

*Numbers in columns 1, 2, 3, and 4 correspond with wave 1, wave 2, wave 3, and wave 4 respondents, respectively.

**Labor force participants are classified here as individuals who are either currently employed (i.e., at the time of the interview for the relevant wave), or if not employed, have either worked or searched for work within the last year.

$* * *$ Full-time workers are classified here as individuals working at least 35 hours/week on their primary job. ****Underemployed workers refer to individuals who work part-time on their primary job, but desire to work more hours on the job. The wave 1 survey did not contain questions about desired work hours.

Despite the large increase in full-time employment over the 5-year period, many workers' hours were constrained. Roughly three of five of the 35.2 percent of women who worked part-time at wave 3 were underemployed-i.e., worked parttime, but wanted to work more hours on their main job. ${ }^{9}$ At both waves 3 and 4, roughly one-third of all respondents were either unemployed or underemployed.

The increases in wages, work hours, and health benefits led to improvements in job quality. At wave 1, only 15.1 percent of workers worked full-time at jobs that paid $\$ 7.00$ or more per hour; by wave $4,46.3$ percent of working respondents held such jobs. At wave 1, only 13.5 percent of working respondents had "good" jobs; by wave 4, 45.8 percent of working respondents held "good" jobs. ${ }^{10}$ Despite improvements in labor market outcomes between fall 1997 and fall 1999 during

\footnotetext{
${ }^{9}$ The wave 1 survey did not contain questions about desired work hours.

${ }^{10}$ Because the wave 1 survey did not ask about desired work hours, we did not include voluntary parttime workers in this figure-11 percent of the employed sample at wave 1 met the wage and benefit criteria for a "good" job, but worked part-time.
} 
the economic boom, 62 percent of employed respondents at wave 3 were not working in "good" jobs. ${ }^{11}$ This fell slightly to 54.2 percent by fall 2001/winter 2002.

Table 3 shows movements across successive waves between nonemployment, working in a bad job, and working in a good job. (Note that a woman can move from a bad job to a good job either by getting raises or promotions on the same job or by changing jobs.) Both stability and volatility in job quality are evident across waves. Between 51 and 59 percent of women had the same employment state at waves $t$ and $t+1$ (the on-diagonal elements). Employment status also changed considerably across waves. On the positive side, 21.5 percent of women in bad jobs at wave $t$, and 13.5 percent of women not employed at wave $t$, moved into good jobs by wave $t+1$. On the negative side, 25.4 percent of women in good jobs at wave $t$ worked at bad jobs at wave $t+1$, and 15.1 percent of women in good jobs at wave $t$ were not employed at wave $t+1$. That is, 40 percent of women in good jobs at wave $t$ were not in good jobs at wave $t+1$.

Tables $3 \mathrm{~b}$ and $3 \mathrm{c}$ illustrate the effect of changes in economic conditions by contrasting job quality transition patterns for the period fall 1997-1999 of tight labor

Table 3. \% Changing Job Quality Status Between Successive Waves.

Table 3a. Movements across successive waves between nonemployment, working in a bad job, and working in a good job.

\begin{tabular}{lccc}
\hline & Not Employed & $\begin{array}{c}\text { Wave } t+1 \\
\text { Bad Job }\end{array}$ & Good Job \\
\hline $\begin{array}{l}\text { Wave } t \\
\text { Not employed } \\
\begin{array}{l}\text { Row percent } \\
\text { Bad job }\end{array}\end{array}$ & $51.0 \%$ & $35.5 \%$ & \\
$\begin{array}{l}\text { Row percent } \\
\text { Good job }\end{array}$ & $22.7 \%$ & $55.8 \%$ & $13.5 \%$ \\
Row percent & $15.1 \%$ & $25.4 \%$ & $21.5 \%$ \\
Column percent & $29.9 \%$ & $43.9 \%$ & $59.5 \%$ \\
\hline
\end{tabular}

Based on the sum of 3 two-year transition matrices, WES waves 1-4 (1997-2001).

Sample restricted to individuals observed in at least two waves that contain non-missing values for wages, hours, and health benefits.

Table 3b. Percentage changing job quality status between fall 1997-1999.

\begin{tabular}{|c|c|c|c|c|c|c|c|}
\hline & $\begin{array}{c}\text { Not } \\
\text { Employed }\end{array}$ & $\begin{array}{l}\text { Fall '99 } \\
\text { Bad Job }\end{array}$ & Good Job & & $\begin{array}{c}\text { Not } \\
\text { Employed }\end{array}$ & $\begin{array}{l}\text { Fall '01 } \\
\text { Bad Job }\end{array}$ & Good Job \\
\hline Fall '97 & & & & Fall '99 & & & \\
\hline Not Employed & & & & Not Employed & & & \\
\hline Row percent & $39.4 \%$ & $41.1 \%$ & $19.4 \%$ & Row percent & $57.1 \%$ & $29.3 \%$ & $13.6 \%$ \\
\hline Bad Job & & & & Bad Job & & & \\
\hline Row percent & $22.0 \%$ & $49.5 \%$ & $28.6 \%$ & Row percent & $28.6 \%$ & $48.7 \%$ & $22.8 \%$ \\
\hline Good Job & & & & Good Job & & & \\
\hline Row percent & $12.8 \%$ & $23.4 \%$ & $63.8 \%$ & Row percent & $13.9 \%$ & $24.8 \%$ & $61.3 \%$ \\
\hline Column percent & $27.2 \%$ & $44.2 \%$ & $28.6 \%$ & Column percent & t $32.5 \%$ & $36.7 \%$ & $30.7 \%$ \\
\hline
\end{tabular}

Table 3c. Percentage changing job quality status between fall 1999-2001.

${ }^{11}$ Even when we exclude health benefits as a criterion for a good job, only 27.2 percent of the total sample (42.8 percent of the employed sample) held good jobs at wave 3 . 
demand with the period fall 1999-2001 of a more sluggish economy. The transition rates into good jobs were higher between 1997 and 1999 across all employment states. The 1999-2001 period shows less upward mobility, as higher proportions of women were nonemployed at the beginning and end of this period, lower fractions of women successfully transitioned into good jobs from bad ones, and lower fractions of women held onto good jobs.

Table 4 reports job quality at wave 4 by the number of months in which respondents worked over the roughly 5 years (56 to 61 months) since the sample was drawn. ${ }^{12}$ The number of months worked varied considerably. Of the respondents, 16 percent had worked in every month of the previous 5 years, and nearly 70 percent had worked in 65 percent or more of the months. Fewer than 5 percent had never worked, and 27 percent had worked in some, but not most, of the months.

The probability of holding a good job at wave 4 is positively associated with the regularity of employment. Yet, even among the 16 percent of respondents who had worked in every month of the past 5 years, only 55 percent were employed in "good" jobs; and fewer than 40 percent of those respondents who had worked in most of the months of the past 5 years were working in good jobs. Although regular work improved women's chances of working at a good job, the majority of women who had worked regularly over roughly a 5-year period were still not working in good jobs by wave 4 .

One reason extensive work experience may not lead to a good job for former and current TANF recipients is that they work at jobs that provide few on-the-job training opportunities to acquire the skills necessary to move into good jobs. The employer survey (MES) is used to examine the characteristics of jobs filled by previously hired welfare recipients (within the last 2 years) and the skills and credentials of the former recipients who obtained these jobs. These results are presented in columns 1 and 2 of Table 5.

Table 4. Job quality at wave 4 by work involvement over previous 5 years.

\begin{tabular}{lcrrrr}
\hline & Total Sample & \multicolumn{3}{c}{$\begin{array}{c}\text { Percent of Months Worked } \\
(\sim \text { past 5 years })\end{array}$} \\
& & \multicolumn{3}{c}{$\begin{array}{c}\text { Most } \\
\text { None/Few }\end{array}$} & $\begin{array}{c}\text { Some } \\
\text { All }\end{array}$ \\
\% of Sample & & $0-19 \%$ & $20-64 \%$ & $65-99 \%$ & $100 \%$ \\
Number of respondents** & $100 \%$ & $4.7 \%$ & $27.4 \%$ & $52.1 \%$ & $15.8 \%$ \\
Wave 4 & 507 & 24 & 139 & 264 & 80 \\
$\%$ Unemployed & $31.2 \%$ & $77.3 \%$ & $56.8 \%$ & $22.4 \%$ & $2.5 \%$ \\
$\%$ Employed in bad jobs & $37.3 \%$ & $22.7 \%$ & $30.2 \%$ & $40.5 \%$ & $42.5 \%$ \\
$\%$ Employed in good jobs & $31.6 \%$ & $0.0 \%$ & $13.0 \%$ & $37.1 \%$ & $55.0 \%$ \\
\hline
\end{tabular}

*Table contains descriptives of the quality of jobs obtained by wave 4, roughly 5 years (56-61 months) after the sample was drawn from the welfare rolls in February 1997.

**Includes only labor force participants where they are classified here as individuals who are either currently employed (i.e., at the time of the interview for the relevant wave), or if not employed, have either worked or searched for work within the last year.

12 Table 4 includes only labor force participants, classified here as individuals who are either currently employed (i.e., at the time of the interview), or if not employed, have either worked or searched for work within the last year. 
Roughly half of employers had hired a recipient in the past two years- 25 percent of jobs filled by previously-hired recipients were good jobs, while 75 percent were not. A clear pattern emerges-good jobs require more skills than bad jobs, but all jobs require skills. For example, among previously-hired recipients holding bad jobs, nearly 90 percent were high school graduates (or had GEDs); 46.8 percent had occupation-specific experience, and 29 percent had some type of skill certification. These much higher skill credentials of previously hired recipients, relative to the WES sample, are likely due to the ability of the most highly skilled recipients to obtain jobs and leave the rolls first. Among the more detailed job categories in which these previously hired recipients were employed are cashiers, receptionists, general office clerks, restaurant workers, nurses aids, and maids and janitors.

Table 5. Skills, credentials, and characteristics of jobs of previously hired welfare recipients.

\begin{tabular}{|c|c|c|c|c|c|}
\hline & & oyer & Former/Cu & ent Welfare & ecipients \\
\hline & $\begin{array}{c}\text { Good Jobs } \\
\text { Filled by } \\
\text { Previously } \\
\text { Hired } \\
\text { Recipients } \\
\text { (25\% of } \\
\text { sample) } \\
1\end{array}$ & $\begin{array}{c}\text { Bad Jobs } \\
\text { Filled by } \\
\text { Previously } \\
\text { Hired } \\
\text { Recipients } \\
\text { (75\% of } \\
\text { sample) } \\
2\end{array}$ & $\begin{array}{l}\text { Unemployed } \\
\text { (29\% of } \\
\text { sample) }\end{array}$ & $\begin{array}{c}\text { Employed } \\
\text { in Bad Job } \\
\text { (45\% of } \\
\text { sample) }\end{array}$ & $\begin{array}{l}\text { Employed } \\
\text { in Good } \\
\text { Job }(26 \% \\
\text { of sample) }\end{array}$ \\
\hline Credentials: & & & & & \\
\hline HS/GED & 95.9 & 87.7 & 58.3 & 73.8 & 83.1 \\
\hline Occup. Exp. & 66.7 & 46.8 & & & \\
\hline Skill cert. & 47.4 & 29.0 & & & \\
\hline None of the above & 2.7 & 4.7 & & & \\
\hline Tasks: & & & & & \\
\hline Reading/writing & 53.8 & 42.2 & 43.9 & 53.0 & 72.3 \\
\hline Arithmetic & 62.5 & 67.4 & 49.6 & 66.8 & 69.6 \\
\hline Computer & 52.5 & 40.8 & 20.2 & 26.4 & 42.6 \\
\hline Customer contact & 62.5 & 79.0 & 59.1 & 83.9 & 73.9 \\
\hline None of the above & 10.0 & 10.8 & 25.5 & 8.7 & 6.2 \\
\hline Task Combinations: & & & & & \\
\hline $\begin{array}{l}\text { Reading, writing, \& } \\
\text { computer }\end{array}$ & 37.5 & 21.6 & 14.6 & 19.2 & 35.2 \\
\hline $\begin{array}{l}\text { Reading, writing, \& } \\
\text { no computer }\end{array}$ & 16.3 & 20.7 & 29.4 & 33.8 & 37.1 \\
\hline $\begin{array}{l}\text { Arithmetic but no } \\
\text { reading/writing }\end{array}$ & 26.3 & 31.0 & 20.9 & 27.2 & 15.1 \\
\hline No hard skills & 15.0 & 22.4 & 34.6 & 18.9 & 11.2 \\
\hline Occupation: & & & & & \\
\hline Clerical & 41.3 & 14.3 & 7.3 & 8.9 & 16.7 \\
\hline Sales & 7.5 & 23.8 & 20.0 & 25.2 & 10.3 \\
\hline Blue-collar & 26.3 & 16.5 & 23.1 & 13.2 & 25.6 \\
\hline Service & 23.8 & 44.2 & 28.7 & 44.8 & 31.4 \\
\hline No recent work exp. & & & 15.0 & - & - \\
\hline
\end{tabular}

In columns 3-5, job quality outcomes at waves 2, 3, and 4 are pooled and correspond with the pooled average proportion of respondents that were unemployed, employed in bad jobs, and employed in good jobs, respectively; recipient job skill experience corresponds with job skills used (occupation worked in) in past year of relevant wave of employment outcome. 
Do former and current welfare recipients have the necessary credentials and skills to compete for jobs, particularly good jobs? Columns 3, 4, and 5 of Table 5 report the skills and credentials of the WES sample of TANF recipients by their employment status-unemployed, employed in bad job, or employed in good job. ${ }^{13}$ The associations between credentials, skills, and WES respondents' employment outcomes (columns 3, 4, and 5) mirror the associations between credentials, tasks, and quality of entry-level jobs reported by employers (columns 1 and 2). More than 80 percent of those employed in good jobs were high school graduates (or had obtained a GED), while only 58 percent of the unemployed had a degree. Of women employed in a good job 72 percent had performed reading and writing daily on a job held over the past year, compared with 43.9 percent of the unemployed. Of women with a good job 35 percent had performed both reading and writing and computer skills on past jobs, compared with only 19 percent of women in a bad job, and 14.6 percent of unemployed women.

The bottom part of Table 5 shows that good jobs filled by previously hired welfare recipients (column 1) are concentrated in clerical (41.3 percent) and blue-collar occupations (26.3 percent), while service jobs make up 44 percent of bad jobs (column 2). These occupation distribution patterns are similar to those observed in the WES sample of TANF recipients. Of WES women employed in bad jobs 45 percent worked in service occupations (column 4).

Comparing the skills and credentials of former and current recipients who are unemployed or are employed in a bad job with the skill and credential requirements of good jobs, suggests that hard skill deficiencies (i.e., deficiencies in reading and writing, arithmetic, or computer skills) prevent some current and former welfare recipients from making the transition to a good job. For example, 34.6 percent of the unemployed have not worked in a job requiring hard skills, while 85 percent of good jobs require at least one hard skill, and usually require multiple hard skills.

A lack of cognitive skills may affect not only the kind of job some recipients can get, but, because of fewer on-the-job training opportunities, may also affect their potential for wage growth. MES collected information from employers on the chances of upward mobility in jobs of different skill level filled by previously hired recipients. As Holzer (1999b) acknowledges, employer reports of potential wage increases for merit and chances for promotion are likely upward-biased, since employers may consider it more socially acceptable to claim that they are willing to offer chances of upward mobility. Still, the differences in these reports in jobs that require reading, writing, and computer skills compared with jobs that require only soft skills offer useful comparisons of the potential for wage growth and chance for promotion in jobs of different skills. Based on employers' reports, jobs filled by previously hired recipients that require reading, writing, and computer skills were more likely to offer potential wage increases for merit and greater chances for promotion (with good performance), and were more likely to offer formal job training opportunities. Recipients who received formal job training and worked in jobs requiring reading, writing, and computer skills experienced almost twice the number of formal job training hours relative to those holding a job that required only soft skills (results not shown). ${ }^{14}$ Since on-the-

\footnotetext{
${ }^{13}$ In columns 3-5 of Table 5, job quality outcomes at waves 2, 3, and 4 are pooled; recipient job skill experience corresponds with job skills used (occupation worked in) in the past year of relevant wave of employment outcome.

${ }^{14}$ Previous research has documented that most employer-provided training is short and intensive, concentrated during the first four weeks of the job spell (Lynch, 1991). Thus, the observed differences in the amount of hours of job training are not likely to be driven by potential differences in job turnover rates between these jobs.
} 


\section{Job Quality and Job Transition Patterns after Welfare Reform / 629}

job training typically provided in non-college jobs is not firm-specific ${ }^{15}$ (i.e., training that is valued within the firm but less easily transferable to other jobs), but rather consists of general and occupation-specific training, these opportunities may be of special importance for low-skilled workers. ${ }^{16}$

Among the welfare recipients who were hired in the firms from the MES, almost one-third were no longer working for their employer, indicating a reasonably high amount of job turnover during the relatively short periods that had elapsed since most were hired (Holzer, 1999b). ${ }^{17}$ Overall work experience accumulated masks heterogeneity in job transition patterns, which may have significant effects on wage growth trajectories (Johnson, 2003). While most WES respondents have worked in most months over the past 5 years, with much of this work in full-time jobs, job instability was the most common employment pattern between waves. Table 6 displays the job transition patterns between the most recent job of successive waves. Roughly half of the respondents experienced job instability, while 29.6 percent experienced job stability and 21.9 percent experienced job mobility between successive waves. ${ }^{18}$

Why is job instability so prevalent? Women who were working at wave 1 were asked if they expected to be working in their current job less than 6 months, 6 months to 1 year, 1 to 2 years, or longer than 2 years. Of those working at Wave 1,63 percent expected to be working in the same job at wave 2 , but only 38 percent actually still worked at the same job. The fraction of women who experienced job stability over a 2-year period more than doubled for fall 1999 to fall 2001 , relative to the fraction of women who experienced job stability during the preceding 2-year period (increasing from 12.5 percent to 33.1 percent (data not shown).

On the other hand, the worsening economic conditions in 2001 increased the risk of job loss. As shown in Table 6, among individuals who experienced job separation between waves, separation resulting from being fired or laid-off increased from 21.3 to 27.9 percent between $1998-1999$ and 1999-2001. As the economy contracts, individuals with the weakest skills and least work experience lose their jobs first, leaving many former and current recipients highly vulnerable to layoffs.

The primary reason reported for job separation between waves 2 and 3 were: 21.3 percent were fired or laid-off; 21.3 percent quit because of job-related problems (including dissatisfaction with current job, such as inadequate pay, poor working conditions, suboptimal hours, poor job match); 10.3 percent had child care concerns; 9.4 percent had health problems; 7.6 percent had a transportation problem; 2.7 percent had family problems or pressure; 27.4 percent had other reasons. The large proportion reporting non-job-related reasons (57.4 percent) is consistent with the substantial job instability experienced by these women. These descriptive results motivate our regression model of job quality estimated in the next section.

\footnotetext{
15 The proportion of on-the-job training opportunities that are firm-specific rises with the skill level and education requirements of the job (Simpson, 1992).

${ }^{16}$ See, for example, Lynch (1991) for evidence on the effects of on-the-job training on wage growth and job mobility patterns of female workers.

${ }^{17}$ Over 60 percent of the employees in this category were hired in 1997, and the median duration of time that had expired since the time of hiring was about six months for this sample (Holzer, 1999b). As Holzer notes, a 31 percent turnover rate for a sample of roughly a six-month period is considerably higher than the national average of about 40 percent (Anderson and Meyer, 1994).

18 These results are consistent with those of Royalty (1998) and Holzer and LaLonde (2000), who found that job-to-nonemployment changes were more frequent than were job-to-job changes among young women with low levels of schooling.
} 
Table 6. Job transition patterns.

Avg job transition pattern between most recent job of successive waves Job stability

Self-reported primary reason for job separation between wave $2 \& 3$ Fired/laid-off

Job-related quit

Childcare concern

Own health problem

Transportation problem

Family problem/pressure Other
$21.3 \%$

$21.3 \%$

$10.3 \%$

$9.4 \%$

$7.6 \%$

$2.7 \%$

$27.4 \%$
Self-reported primary reason for job separation between wave $3 \& 4$ Fired/laid-off Job-related quit $27.9 \%$ Childcare concern $\quad 7.6 \%$ Own health problem $\quad 11.4 \%$ Transportation problem $\quad 3.5 \%$ Family problem/pressure $\quad 4.4 \%$ Other

\section{Empirical Strategy and Model Specification}

What particular job skills and types of work experience enable recipients to obtain a good job or successfully transition into one from a bad job? We estimate equation 1 , which specifies the hazard-i.e., the probability of transitioning from a bad job to a good job in a given year (conditional on the individual working in a bad job at the beginning of the period):

$$
h(t)=\frac{1}{[1-\exp (\beta \mathrm{X}(t)]}
$$

where $X(t)=\beta_{0-1}$ EDUC $_{i t}+\beta_{2}$ WKEXP $_{i t}+\beta_{3-12}$ JOBSKILLS $_{i,(t-1, t)}+\beta_{13}$ JSTABLTY $_{\mathrm{i},(\mathrm{t}-1, \mathrm{t})}+\beta_{14}$ JMOBILE $_{i,(t-1, t)}+\beta_{15}\left(\mathrm{JMOBILE}_{i,(t-1, t)} * \mathrm{WKEXP}_{i t}\right)+$ $\beta_{16}$ UNEMPRATE $_{t}+\beta_{17} \mathrm{UNION}_{i t}+\beta_{18-22} Z_{i t}+\beta_{23-26}$ HLTH $_{i t}+\beta_{27}$ DUR $_{i,(t-1, t)}+\beta_{28}$ $\mathrm{WAGE}_{i, t-1}+\boldsymbol{\epsilon}_{i t}$

where: $h(t)=$ the hazard of transitioning from a bad job to a good job, $t=2,3,4$

EDUC = educational attainment: high school diploma or GED; whether some college.

WKEXP $=$ work experience as of $t$.

JOBSKILLS $=$ job skills used in job(s) held between $(t-1)$ and $t$; job performance in the last month of most recent job $(t)$; whether has learning disability; whether passed reading test.

JSTABILITY $=$ whether held the same job at $(t-1)$ and $t$.

JMOBILE $=$ whether experienced job mobility between $(t-1)$ and $t$.

UNEMPRATE $=$ monthly county unemployment rate

$\mathrm{UNION}=$ whether union member at current or most recent job $(t)$.

$\mathrm{Z}$ = demographic variables: age of children, whether pregnant (past yr), whether married and cohabitating, and race.

HLTH $=$ health-related measures at $t$ : physical limitations, mental health problems, child health problems, severe physical abuse.

DUR $=$ duration of time (in months) that has elapsed between $(t-1)$ and $t$.

WAGE = hourly wages on current or most recent job held at ( $t-1)$. 
In equation 1 , time $t=2,3$, and 4 corresponds with the time of the most recent job of individual $i$ as of the survey interview dates of waves 2,3 , and 4, respectively. The wages, hours, and health benefits of the most recent job are recorded at each interview (given the individual has worked at some point between interviews). ${ }^{19}$ Our multivariate analysis focuses on the quality of employment opportunities, rather than on the labor supply preferences, of respondents. Thus, the analysis is restricted to labor force participants and individuals working voluntarily part-time are classified as possessing a good job if their wages and benefits on their job meet the wage and benefit criteria for a good job. ${ }^{20}$ One can transition from a bad job to a good job either through pay raises, increased hours, or promotions at the same job, or by switching to a new and better job. ${ }^{21}$

The coefficients on the job skills variables measure the extent to which the skill content of recent experience is associated with an increased likelihood of moving into a good job. The coefficient on the health and safety variables measure the extent to which health-related problems are associated with a lower likelihood of moving into a good job. The wage controls for how close a woman was to a good job threshold at $(t-1)$.

Whether consistent work experience in a bad job is a better pathway to a good job is analyzed relative to accumulating no work experience or intermittent work experience, by including the set of job transition pattern variables, and the aggregate number of years of work experience accumulated as of $t$. The job transition pattern variables JMOBILE and JSTABLTY measure whether the individual experienced job mobility, instability, or stability over the past year. The impact of job separation on the probability of moving into a good job is of interest. Individuals are classified as experiencing job instability when job separations are the result of being fired or laid-off, or when job-to-nonemployment transitions last more than a month. Nonemployment spells of more than a month are less likely to result from a voluntary separation, and are more likely to result from nonmarket and nonsearch reasons. Individuals who had voluntary job-to-job changes without intervening spells of nonemployment of a month or more are classified as experiencing job mobility.

A greater likelihood of moving into a good job is expected for individuals who experienced job mobility-since they presumably voluntarily changed jobs because they expected a total compensation gain - than for individuals who experienced job instability-because of losses in job-specific human capital and matching capital, and because employers use the stability of potential workers' employment history as a signal for a good match (Gladden and Taber, 2000). Returns to job stability (individuals whose current or most recent job in wave $t$ was the same as that held in the previous wave) are also expected to be higher than those to job instability. Because the timing of job mobility in a worker's career (as well as the extent of overall job mobility) has been shown to be important (Bartel, 1980; Light and McGarry, 1998), interactions between job mobility and work experience are included. The returns to job mobility are expected to be largest early in one's career.

Job mobility decisions are likely endogenous with respect to improvements in job quality. One reason individuals stay in the same job is because the job has more potential wage growth opportunities. This produces a downward bias on the estimated effects of job mobility (relative to job stability), since the counterfactual-the

\footnotetext{
${ }^{19}$ Since only about 10 percent of the sample did not work over the entire period (and thus lacks wage information), selection bias should not be a major concern.

${ }^{20}$ We have also run these analyses using alternative definitions of good job and bad job (e.g., relaxing the health benefit requirement of good jobs), but none qualitatively changed the findings reported.

${ }^{21}$ We classify individuals as transitioning from a bad job to a good job only if the individual is still currently working in the good job at the relevant survey interview.
} 
improvement in job quality the individual would have experienced had she stayed in the same job-is not observed. In this way, the estimates of the gains to job mobility (relative to job stability), ( $\beta 14-\beta 13)$, may be considered lower bound estimates.

The inclusion of the monthly county unemployment rate captures the impact of changes in local economic conditions-i.e., the effect of worsening economic conditions after early 2001 (between waves 3 and 4), relative to the period of tight labor demand and strong economic growth that occurred between 1997 and 1999 (waves $1-3)$. Increases in the availability of jobs increase work through increases in the frequency and quality of job offers and stability of employment (Hoynes, 2000). Labor market conditions affect wage levels and the probability of finding and keeping employment.

The coefficients on our explanatory variables are given no structural or causal interpretation, as the hazard model does not control for unobserved heterogeneity (e.g., unobserved characteristics such as work attitudes or motivation remain a potential source of bias). Instead, our hazard model summarizes the relationships between various dimensions of job skills, work experience, health issues, employment patterns, economic conditions, and demographic characteristics, and the probability of transitioning from a bad job to a good job.

\section{REGRESSION RESULTS}

The final column of Table 7 reports the average 1-year percentage change in the hazard rate of transitioning from a bad job to a good job associated with a discrete change in each of the explanatory variables. These average percentage changes are estimated using the coefficients reported in column 2 of Table 7. Due to the nonlinearity of the model, average effects of discrete changes in explanatory variables are calculated by evaluating the effect of varying the explanatory variable of interest in a given way for each individual (holding all other variables constant, evaluated at a 1-year interval), and then computing the mean of these effects (e.g., the percentage change in the hazard). The mean predicted 1-year hazard rate of transitioning from a bad to a good job is 15.6 percent.

The results indicate that post-secondary schooling and years of work experience ${ }^{22}$ are positively and significantly associated with transitioning from a bad job to a good job between waves. In particular, having some post-secondary schooling (relative to being a high school dropout) is estimated to increase the probability of transitioning into a good job by 40 percent, and an additional year of work experience is estimated to increase the probability by 3.4 percent. Having a high school diploma or equivalency increases the probability of transitioning to a good job in a given year by 15 percent, but this effect was not statistically significant.

Comparing the results from the full model specification displayed in Table 7 with results from a parsimonious specification that excluded the set of job skill and job transition variables, suggests that part of the return to education is in the form of higher probabilities of job-to-job upgrading and mobility (within and across firms). (These results are not shown in the table, but are available from the authors upon request.) The coefficient on post-secondary schooling and years of work experience drops in magnitude but remains significant with the inclusion of the extensive set of job skill and job transition variables.

22 Alternative specifications for work experience that had a quadratic term, as well as specifications that distinguished full-time and part-time work did not significantly improve the fit of the model. 
Table 7. Percentage change in the hazard rate of transitioning from a bad job to a good job.

\begin{tabular}{|c|c|c|c|c|}
\hline & $\begin{array}{c}\text { Change in } \\
\text { Variable }\end{array}$ & $\begin{array}{c}\text { Coef } \\
\text { Estimates }\end{array}$ & Robust SE & $\begin{array}{l}\% \text { Change } \\
\text { in Hazard }\end{array}$ \\
\hline Human Capital Variables & (1) & $(2)$ & (3) & (4) \\
\hline \multicolumn{5}{|l|}{ Dropout (reference category) } \\
\hline HS Grad/GED & 0 to 1 & 0.1643 & $(0.2318)$ & $15.2 \%$ \\
\hline Some College & 0 to 1 & $0.3966^{*}$ & $(0.2410)$ & $40.0 \%$ \\
\hline Years of Work Experience & 0 to 1 & $0.0380 * *$ & $(0.0175)$ & $3.4 \%$ \\
\hline \multicolumn{5}{|l|}{ Job Skills (used b/w (t-1) and $\mathrm{t}$ ): } \\
\hline $\begin{array}{l}\text { Reading/Writing } \\
\text { Computers }\end{array}$ & $\begin{array}{l}0 \text { to } 1 \\
0 \text { to } 1\end{array}$ & $\begin{array}{l}0.4828 * * \\
0.3499 *\end{array}$ & $\begin{array}{l}(0.2014) \\
(0.1921)\end{array}$ & $\begin{array}{l}51.0 \% \\
34.1 \%\end{array}$ \\
\hline Arithmetic & 0 to 1 & 0.0543 & $(0.2202)$ & $4.7 \%$ \\
\hline Complete Forms & 0 to 1 & $0.3471 *$ & $(0.2051)$ & $34.4 \%$ \\
\hline Gauges/Instruments & 0 to 1 & $0.3411^{*}$ & $(0.1755)$ & $33.5 \%$ \\
\hline Supervise Co-workers & 0 to 1 & $0.4345 *$ & $(0.1782)$ & $43.9 \%$ \\
\hline Serving Customers & 0 to 1 & $-0.6441 * * *$ & $(0.2230)$ & $-40.8 \%$ \\
\hline Work Performance-related problem & 0 to 1 & $-0.3586 *$ & $(0.2089)$ & $-26.4 \%$ \\
\hline Below 6th grade Reading Competency & 0 to 1 & -0.1122 & $(0.2542)$ & $-9.1 \%$ \\
\hline Learning Disability & 0 to 1 & -0.3121 & $(0.2434)$ & $-23.5 \%$ \\
\hline \multicolumn{5}{|l|}{ Job Transition Variables $(\mathrm{b} / \mathrm{w}(\mathrm{t}-1)$ and $\mathrm{t})$} \\
\hline Job Stability & 0 to 1 & 0.2569 & $(0.2048)$ & $24.4 \%$ \\
\hline Voluntary Job Change & 0 to 1 & $0.7927 * *$ & $(0.3419)$ & $91.6 \%$ \\
\hline \multicolumn{5}{|l|}{ Voluntary Job Change * } \\
\hline Work Experience & & -0.0424 & $(0.0315)$ & \\
\hline \multicolumn{5}{|l|}{$\begin{array}{l}\text { Local Labor Market Demand } \\
\text { Conditions }\end{array}$} \\
\hline Monthly County Unemp Rate & $4.5 \%$ to $7.5 \%$ & $-0.1225 * *$ & $(0.0602)$ & $-26.7 \%$ \\
\hline Union & 0 to 1 & $0.7218^{* * * *}$ & $(0.2165)$ & $80.2 \%$ \\
\hline \multicolumn{5}{|l|}{ Demographic Variables } \\
\hline Child $0-2$ years old & 0 to 1 & -0.2272 & $(0.2176)$ & $-17.6 \%$ \\
\hline Child 3-5 years old & 0 to 1 & 0.1234 & $(0.1687)$ & $11.0 \%$ \\
\hline Pregnant $\mathrm{b} / \mathrm{w}(\mathrm{t}-1)$ and $\mathrm{t}$ & 0 to 1 & -0.2086 & $(0.2673)$ & $-16.3 \%$ \\
\hline Married/Cohabiting & 0 to 1 & 0.0753 & $(0.1880)$ & $6.6 \%$ \\
\hline Black & 0 to 1 & 0.0731 & $(0.1751)$ & $6.4 \%$ \\
\hline \multicolumn{5}{|l|}{ Health-related Variables } \\
\hline Wk-limiting (physical) health cond'n & 0 to 1 & -0.2398 & $(0.2378)$ & $-18.5 \%$ \\
\hline Child health problems & 0 to 1 & -0.1797 & $(0.2469)$ & $-14.2 \%$ \\
\hline Mental health cond'n & 0 to 1 & -0.2161 & $(0.1882)$ & $-16.8 \%$ \\
\hline Domestic Violence (past year) & 0 to 1 & -0.0816 & $(0.2255)$ & $-6.7 \%$ \\
\hline \multicolumn{5}{|l|}{ Duration of Time $b / w(t-1)$ and } \\
\hline Hourly Wage as of (t-1) & $\$ 5$ to $\$ 6$ & $0.0643 *$ & $(0.0395)$ & $5.6 \%$ \\
\hline Constant & & $-3.2306 * * *$ & $(0.5064)$ & \\
\hline $\begin{array}{l}\text { Mean Predicted One-Year Hazard Rate } \\
\text { Log-Likelihood } \\
\text { \# of Observations (\# of Subjects) }\end{array}$ & & $\begin{array}{r}0 \\
-50 \\
118\end{array}$ & $\begin{array}{l}55 \\
6581 \\
(586)\end{array}$ & \\
\hline
\end{tabular}

$* p<0.10, \quad * * p<0.05, \quad * * * p<0.01$ 
The results reported in Table 7 illuminate the importance of job skills. Individuals who used reading, writing, or computer skills daily on a job held over the past year and individuals who had supervised co-workers in the past year were significantly more likely to make the transition from a bad job to a good job; while individuals who worked in a job that involved serving customers daily (either by phone or in person) were significantly less likely to make this transition. On average, having recent experience in jobs that required reading and writing increased the 1-year hazard by 51 percent; experience with computers increased the hazard by 34 percent; and experience serving customers reduced it by 41 percent.

Some analysts have contended that a subset of current and former welfare recipients either do not know or do not conform to common standards of work behavior, and that this reduces their chances of upward mobility. Of respondents, 18 percent had work performance problems (for the measure of work performance-related problems, see Appendix A). The coefficient on the measure of work performance problems (e.g., rudeness to customers, leaving early, refusing to do job tasks) is negative and significant, suggesting that work performance problems may play an important role in reducing women's chances of gaining good jobs. In particular, having work performance problems decreased the probability of transitioning from a bad job to a good job in a given year by 26 percent. Our results also indicate that having learning disabilities decreases the probability of transitioning into a good job by 24 percent (though the coefficient is only marginally significant).

Voluntary job mobility is associated with improvements in job quality outcomes, while individuals experiencing job instability are significantly less likely to transition to a good job, relative to individuals who remain in the same job. On average, relative to job instability, voluntary job mobility is associated with a 92 percent predicted increase in the 1-year hazard rate of making the transition from a bad job to a good job, and job stability is associated with a 24 percent increase in the hazard rate. The negative coefficient on the "voluntary job change*work experience" interaction term shows that the return to voluntary job changes are greater early in one's career, as predicted by job matching theory.

Local economic demand conditions have significant effects. We simulate the effect of a 3 percentage-point increase in the unemployment rate. This simulated change in local economic demand conditions, represents the typical withincounty change observed over the 1997-2002 period and can be interpreted as the variation that might be expected between the trough and peak of a business cycle. The results indicate that a 3 percentage-point increase in the unemployment rate is estimated to decrease the 1-year hazard rate of transitioning to a good job by 27 percent. The probability of making the transition from a bad job to a good job is estimated to decrease by roughly 10 percent with each additional percentagepoint increase in the local unemployment rate. The economic downturn that occurred in 2001 reduced the probability of transitioning into a good job by 32 percent, relative to the previous periods of tight labor demand (results not shown).

Being a union member increases the probability of moving into a good job by 80 percent. The coefficients on the controls for the duration of time that had elapsed between ( $t-1)$ and $t$ and the hourly wage as of $(t-1)$ were both positive and significant as expected. While the coefficients on the health-related variables were negative, they were not significant. Health-related problems are expected to lower chances of transitioning into a good job primarily by hindering work accumulation and increasing rates of job instability. 


\section{Job Quality and Job Transition Patterns after Welfare Reform / 635}

\section{POLICY IMPLICATIONS}

The results in this paper document both the strengths and limits of the work-first approach adopted by PRWORA. A longitudinal data set of recipients drawn from the rolls in February 1997, shows that despite improvements in job quality and extensive work effort over the 5-year period, job instability and limited upward mobility (i.e., transitions to good jobs) characterized the employment experiences of most respondents. In fall 2001, half were out of the labor force, unemployed, or underemployed, and only about one-quarter were working in good jobs.

Economists traditionally focus the good jobs-bad jobs debate on wages. Employment rates and wages measured at a point in time, however, provide an incomplete picture of the quality of employment outcomes obtained by former and current recipients. In this paper, the analysis of job quality is broadened to include nonwage attributes of compensation and aspects of jobs that affect future earnings potential. Aggregate measures of accumulated work experience are also shown to mask considerable heterogeneity in job transition patterns and job skills used, which both have profound effects on the likelihood of transitioning to a good job.

This work has implications for welfare policy. First, it is too soon to declare that welfare reform has been successful in its stated goal of moving single mothers into self-sufficiency. TANF was implemented during an economic expansion, when unemployment rates had fallen to a three-decade low. Even during this period of tight labor demand, while employment rates increased and job quality improved, many respondents did not achieve a living wage. Also documented are some early negative effects of the recent economic downturn on job transition and job quality outcomes.

Second, evidence from both survey data of former and current recipients and of employers indicates that jobs paying a living wage and jobs that offer the greatest chances of upward mobility have significant hard skills requirements. The assumption that "A job, most any job has shown itself capable of generating the earnings growth that will make welfare reform a reality" (Bonilla, 1995) must be qualified. Training programs aimed at developing the hard skills increasingly valued in the labor market, and placement services that emphasize placing former and current recipients into jobs that require the use of hard skills, may improve these women's upward mobility.

Third, almost half of the women experienced job instability between successive waves, which was associated with a significantly lower likelihood of moving into a good job, relative to job stability or job mobility. More than half of recipients who left a job did so for personal reasons (such as child-care issues). This suggests further implementation of policies and programs aimed at providing women the necessary support to sustain regular employment, and employment service programs that prepare and encourage women to successfully apply for better jobs.

Because most welfare-to-work programs have focused narrowly on job placement, knowledge is unfortunately limited about how to design and implement programs that promote job retention and job advancement. Analyses that inform and evaluate the likely effects of various post-employment services is an important topic for future research.

We are grateful to Sheldon Danziger, Harry Holzer, John Bound, Charlie Brown, Kristin Seefeldt, participants of the University of Michigan Poverty Research Seminar, and several anonymous referees for providing helpful comments on earlier drafts of this paper. We also wish to thank Harry Holzer for providing access to his employer survey data. This research was supported in part by grants from the Charles Stewart Mott Foundation, Ford Founda- 


\section{6 / Job Quality and Job Transition Patterns after Welfare Reform}

tion, Joyce Foundation, the National Institute of Mental Health (R24-M551363), and the Office of the Vice-President for Research at the University of Michigan.

RUCKER C. JOHNSON is Robert Wood Johnson Postdoctoral Research Fellow at the University of Michigan.

MARY E. CORCORAN is Professor in the School of Public Policy at the University of Michigan.

\section{REFERENCES}

Acs, G., \& Loprest, P. (2001). The status of TANF leavers in the District of Columbia. Washington, DC: Urban Institute.

Acs, G., Coe, N., Watson, K., \& Lerman, R. (1998). Does work pay? An analysis of the work incentives under TANF. Washington, DC: Urban Institute.

Anderson, P., \& Meyer, B. (1994). The extent and consequences of job turnover. In Brookings papers on economic activity: microeconomics (pp. 177-236). Washington, DC: Brookings Institution.

Bartel, A. (1980). Earnings growth on the job and between jobs. Economic Inquiry, 18(1), 299-306

Bonilla, C. (1995). ). Hearing on welfare reform. (Testimony before the U.S. House Committee on Economic and Educational Opportunities). Washington, DC: Federal Document Clearing House.

Brock, T., Coulton, C., London, A., Polit, D., Richburg-Hayes, L., Scott, E., Verma, N., Kwakye, I., Martin, V., Polyne, J., \& Seith, D. (2002). Welfare reform in Cleveland: implementation, effects, and experiences of poor families and neighborhoods. New York: MDRC.

Brown, A. (1997). Work first: how to implement an employment-focused approach to welfare reform. New York: MDRC.

Burtless, G. (1995). Employment prospects of welfare recipients. In D.S. Nightingale \& R.H. Haveman (Eds.), The work alternative: welfare reform and the realities of the job market (pp. 71-106). Washington, DC: Urban Institute.

Cancian, M., Haveman, R., Meyer, D., \& Wolfe, B. (2000). Before and after TANF: the economic well-being of women leaving welfare, Special Report No. 77. Madison: University of Wisconsin, Institute for Research on Poverty.

Connolly, H., \& Gottschalk, P. (2001). Returns to tenure and experience revisited: do less educated workers gain less from work experience? (Boston College Working Paper). Boston, MA: Boston College.

DiNardo, J., \& Pischke, J. (1997). The returns to computer use revisited: have pencils changed the wage structure too? Quarterly Journal of Economics, 112(1), 291-303.

Edin, K., \& Lein, L. (1997). Making ends meet. New York: Russell Sage Foundation.

Families USA. (1993). Skyrocketing health inflation 1980-1993-2000: the burden on families and businesses. Washington, DC: Families USA Foundation.

Gladden, T., \& Taber, C. (2000). Wage progression among less skilled workers. In R.M. Blank \& D. Card (Eds.), Finding work: jobs and welfare reform (pp. 160-192). New York: Russell Sage Foundation.

Guyer, J., \& Mann, C. (1999). Employed but not insured. Washington, DC: Center on Budget and Policy Priorities.

Harris, K. (1996). Life after welfare: women, work, and repeat dependency. American Sociological Review, 61(3), 407-426. 


\section{Job Quality and Job Transition Patterns after Welfare Reform / 637}

HHS [U.S. Department of Health and Human Services]. (1987). National medical expenditure survey. Rockville, MD: HHS.

Holzer, H. (1996). What employers want: job prospects for less-educated workers. New York: Russell Sage Foundation.

Holzer, H. (1999a). Employer demand for welfare recipients and the business cycle: Evidence from recent employer surveys. In S. Danziger (Ed.), Economic conditions and welfare reform (pp. 187-218). Kalamazoo, MI: Upjohn Institute for Employment Research.

Holzer, H. (1999b). Will employers hire welfare recipients? Recent survey evidence from Michigan. Journal of Policy Analysis and Management, 18(3), 449-472.

Holzer, H., \& LaLonde, R. (2000). Employment and job stability among less-educated young workers. In D. Card \& R. Blank (Eds.), Finding jobs: work and welfare reform (pp. 125-159). New York: Russell Sage Foundation.

Holzer, H., Stoll, M. \& Wissoker, D. (2001). Job performance and retention among welfare recipients. Discussion paper \# 1237-01 presented as part of the Institute for Research on Poverty. Madison: University of Wisconsin.

Hoynes, H. (2000). The employment, earnings, and income of less-skilled workers over the business cycle. In D. Card \& R. Blank (Eds.), Finding jobs: work and welfare reform (pp. 23-71). New York: Russell Sage Foundation.

Jencks, C., \& Phillips, M. (1998). The black-white test score gap. Washington, DC: Brookings Institution Press.

Johnson, R. (2003). Wage \& job dynamics after welfare reform: the importance of job skills. Unpublished manuscript, Department of Economics, University of Michigan, Ann Arbor.

Juhn, C., Murphy, K., \& Pierce, B. (1993). Wage inequality and the rise in returns to skill. Journal of Political Economy, 101(3), 410-442.

Katz, L., \& Murphy, K. (1992). Changes in relative wages, 1963-1987: supply and demand factors. Quarterly Journal of Economics, 107(1), 35-78.

Krueger, A. (1993). How computers have changed the wage structure: evidence from micro data. Quarterly Journal of Economics, 108(1), 33-60.

Levy, F., \& Murnane, R. (1992). U.S. earnings levels and earnings inequality: a review of recent trends and proposed explanations. Journal of Economic Literature, 30(3), $1333-1381$.

Light, A., \& McGarry, K. (1998). Job change patterns and the wages of young men. Review of Economics and Statistics, 80(2), 276-286.

Loeb, S., \& Corcoran, M. (2001). Welfare, work experience, and economic self-sufficiency. Journal of Policy Analysis and Management, 20(1), 1-20.

Loprest, P. (1992). Gender differences in wage growth and job mobility. The American Economic Review (Papers and Proceedings of the 104th Annual Meeting of the American Economic Association), 82(2), 526-532.

Lynch, L. (1991). The role of off-the-job vs. on-the-job training for the mobility of women workers. American Economic Review, 81(2), 151-156.

Murnane, R., \& Levy, F. (1996). Teaching the new basic skills: principles for teaching children to thrive in a changing economy. New York: Simon and Schuster Free Press.

Murnane, R., Levy, F., \& Willett, J. (1995). The growing importance of cognitive skills in wage determination. Review of Economics and Statistics, 77(2), 251-266.

Pavetti, L., \& Acs, G. (2001). Moving up, moving out, or going nowhere? A study of the employment patterns of young women and the implications for welfare mothers. Journal of Policy Analysis and Management, 20(4), 721-736.

Pavetti, L, Holcomb, P., \& Duke, A. (1995). Increasing participation in work and work-related activities: lessons from five state welfare reform demonstration projects. Washington, DC: Urban Institute. 
Riccio, J., Friedlander, D., \& Freedman, S. (1994). GAIN: benefits, costs and three-year impacts of a welfare-to-work program. New York: MDRC.

Royalty, A. (1998). Job-to-job and job-to-nonemployment turnover by gender and education level. Journal of Labor Economics, 16(2), 392-443.

Simpson, W. (1992). Urban structure and the labor market. New York: Oxford University Press. Topel, R., \& Ward, M. (1992). Job mobility and the careers of young men. Quarterly Journal of Economics, 107(2), 439-479.

Tyler, J., Murnane, R., \& Willett, J. (2000). Do the cognitive skills of school dropouts matter in the labor market? Journal of Human Resources, 35(4), 748-754.

Wallace, G., \& Blank, R. (1999). What goes up must come down? Explaining recent changes in public assistance caseloads. In S. Danziger (Ed.), Economic conditions and welfare reform (pp. 49-90). Kalamazoo, MI: Upjohn Institute.

Ware, J., Snow, K., Kosinski, M., \& Gardek, B. (1993). SF-36 health survey: manual and interpretation guide. Boston, MA: Health Institute, New England Medical Center.

Ziliak, J., Figlio, D., Davis, E., \& Connolly, L. (2000). Accounting for the decline in AFDC caseloads: economic growth or welfare reform? Journal of Human Resources, 35(3), 570-586.

\section{APPENDIX A: DEFINITION OF VARIABLES}

\section{Job Performance Variables}

Using WES, we create a job performance measure to test whether an inability to conform to norms of appropriate work behavior impairs recipients' and ex-recipients' chances of experiencing wage growth and job retention. This measure is a dummy variable that takes the value of 1 if the respondent reported doing any of the following in the last month of their current or most recent job:

- Lost her temper, for example, with a rude customer

- Took a longer break than scheduled without permission

- Failed to correct a problem that a supervisor had pointed out

- Had a problem getting along with a supervisor

- Left work earlier than scheduled without permission

- Refused to do tasks that weren't part of her job description.

Eighteen percent of respondents reported doing one or more of the above in the last month of the current or most recent job held. We include an indicator measure of poor work performance in the regression analysis.

At wave 3, the Wide Range Achievement Test 3 (WRAT3) Reading Test was administered to each WES respondent. The WRAT3 was used in the California Employment Readiness Demonstration Project and has also been used by schools. The results of the WRAT3 are also correlated with results of the California Test of Basic Skills 4 (CTBS-4), the California Achievement Test (CAT), and the Stanford Achievement Test (SAT). We create a dummy variable indicating whether the respondent's reading test score was below 6th grade competency. ${ }^{23}$ We also include a dummy

\footnotetext{
${ }^{23}$ The reading test involves a list of words given to the individual on a separate card. She reads each word until 10 consecutive words are read incorrectly. At this time, the test ends. The time required depends on the speed of the individual taking the test. Each word read correctly earns one point. The sum of points results in a raw score. The test manual indicates how to convert raw scores into absolute scores, standard scores, and grade level scores.
} 
variable indicating whether the respondent self-reported being previously diagnosed with a learning disability. Almost one in five respondents in the sample had reading test scores below 6th grade competency, and 15 percent of women in the sample self-reported being previously diagnosed with a learning disability.

\section{Health and Safety Measures}

WES respondents were asked about their physical health, mental health status, children's health, and about domestic violence experiences in each wave. Women's physical health was assessed using items from the Physical Functioning subscale of the SF-36, which is well-validated and has been widely used (Ware et al., 1993). Respondents were asked a series of questions about whether their health limits their daily activities a lot, a little, or not at all in walking, lifting, climbing stairs, bending, carrying bundles, etc. Respondents who scored in the lowest age-specific quartile (based on population norms) in a wave were defined as having physical limitations.

WES collected data on four mental health disorders: major depression, post-traumatic stress syndrome (PTSD), generalized anxiety disorder (GAD), and social phobia. The measurement of these disorders was based on the definition and the criteria specified in the revised third edition of the American Psychiatric Association's Diagnostic and Statistical Manual of Mental Disorders (DSM-III-R). The diagnosis was operationalized in short-form screening versions of the World Health Organizations (WHO) Composite International Diagnostic Interview (CIDI), a structured interview schedule designed to be used by trained interviewers who are non-clinicians to assess the prevalence of specific psychiatric disorder. Major depression and PTSD are measured in all three waves, GAD in waves 1 and 3, and social phobia in Waves 2 and 3. We define a woman as having a mental health problem in a wave if she met the criteria for any of the mental health disorders measured in that wave. We define a respondent as having a child health problem in a wave if she reported that one of her children had a physical, emotional, or learning problem that limited his and her activity.

Domestic violence was assessed with a modified version of the Conflict Tactics Scale (CTS). In each wave, interviewers asked women whether their partner had ever in the last twelve months used physical threats, physical abuse, sexual abuse, or other coercive actions against them. We define severe abuse in a wave as having experienced one or more of the following in the 12 months prior to the wave interview: being hit with a fist, being hit with an object that could hurt, being beaten, being choked, being threatened with or hurt by a weapon, being forced into sexual activity against her will. 